Frans Hinskens*, Roeland van Hout, Pieter Muysken and Ariën van Wijngaarden

\title{
Variation and change in grammatical gender marking: the case of Dutch ethnolects
}

https://doi.org/10.1515/ling-2020-0265

Received December 3, 2020; accepted December 3, 2020

Abstract: Our research on variation in the expression of grammatical gender (in determiners and adnominal inflection) in present-day ethnolectal Dutch is based on interactional speech data collected among 10-12 and 18-20-year-old male adolescents with Turkish, Moroccan and non-immigrant Dutch backgrounds, born and raised in the Dutch cities of Amsterdam or Nijmegen. The cities, which both have multicultural demographic profiles, are located in different dialect areas. In the data, the realization of neuter gender appears to vary greatly; in our analyses of this variation linguistic and social parameters were included. With regard to the language-internal conditioning, grammatical and semantic dimensions have been taken into account. Apart from the speakers' age and city of residence, the social dimensions also include background of both the speaker and the interlocutor. The outcomes shed light on three aspects. As regards conditioning factors, L1 substrates, processes of L2 acquisition of the first generations of migrants, and surrounding regional variation all play a role. As regards the place of ethnolectal variation in the speakers' verbal repertoires, we found evidence for a stylistic role of variable gender assignment in determiners. Our data do not support the hypothesis of the cross-over of ethnolectal changes in Dutch grammatical gender marking to speakers without an immigrant background.

Keywords: audience design; ethnolect; gender marking; language acquisition; language variation and change

\footnotetext{
*Corresponding author: Frans Hinskens, Meertens Instituut, P.O. Box 94264, 1090 GG Amsterdam, The Netherlands; and Centre for Language Studies, Radboud University Nijmegen, P.O. Box 9103, 6500 HD Nijmegen, The Netherlands, E-mail: frans.hinskens@meertens.knaw.nl

Roeland van Hout and Pieter Muysken, Centre for Language Studies, Radboud University Nijmegen, P.O. Box 9103, 6500 HD Nijmegen, The Netherlands, E-mail: r.v.hout@let.ru.nl (R. van Hout), p.muysken@let.ru.nl (P. Muysken)
}

Ariën van Wijngaarden, De Haagse Hogeschool, The Hague, The Netherlands, E-mail: arienvanwijngaarden@gmail.com 


\section{Introduction}

As cities in industrialized societies become ethnically more complex due to labor migration, the range of varieties in the national languages spoken there increases, and ethnolectal varieties are added to the urban social dialect landscape. Ethnolectal varieties emerge in multilingual contexts and are often rooted in processes of second language acquisition. However, they soon acquire a life of their own, are used by speakers with an immigrant ethnic background, and even cross over to speakers without an immigrant ethnic background (for an overview of ethnolects in the Netherlands see Muysken 2010, 2013).

In the study of ethnolects and immigrant varieties, variation in gender inflection has played an important role for those European languages with strong gender systems: German (cf. e.g., the overview in Clyne 2003; Muysken and Rott 2013), French (cf. e.g., Doran 2002, 2004, 2007; Fagyal and Stewart 2011), and Italian (cf. e.g., Chini 2011). Gender inflection is interesting for several reasons. (a) It lies at the interface between lexical, phonological, and morphosyntactic processing; (b) It is a frequent source of developmental problems for second language learners in these languages.

Examples of the phenomena studied here include the use of the article de instead of neuter het, as in (1) and (2), leading to an overgeneralization of the non-neuter, common gender form ${ }^{1}$ :

(1) ja is goed maar sluit de onderwerp dan sluit de onderwerp [het] 'yes is good, but close the subject then, close the subject'

(Erhan, 47:30)

(2) op het laatst moeten ze naar de leger [het]

'at the end they have to go to the army'

(Volkan, 22:44)

The same holds for the use of the common gender demonstratives deze 'this'/die 'that' instead of the neuter equivalents dit/dat:

(3) dit weekend was die, eh hoe heet die feest ook alweer? [dat] 'this weekend was that, eh what is that party called again?'

(Murat, 7:10)

(4) meester deze plein is een beetje raar [dit]

'teacher this square is a bit strange'

(Volkan, 21:42)

1 In these examples the standard form is presented at the end in square brackets. 
The overuse of the ending $-e$ with indefinite neuter adjectives is quite possibly related to these phenomena:

(5) tegenwoordig komt de krant altijd met eh met negatieve nieuws [negatief] 'these days the newspaper always comes with eh negative news'

(Erhan, 5:29)

(6)

$$
\begin{aligned}
& \text { hij had gele haar) [geel] } \\
& \text { 'he had yellow hair' }
\end{aligned}
$$

(Bilal, 11:23)

To help understand these cases, this article first sketches the expression of grammatical gender in Standard Dutch in contrast with Dutch dialects, Turkish, Moroccan Arabic and Berber (Section 2), and then surveys earlier studies on variation in the expression of grammatical gender in ethnic varieties of Dutch (Section 3). Section 4 describes the Roots of ethnolects project from which the data in this paper are drawn, and Section 5 our main findings. In Section 6, these findings are discussed and a few questions for further research are listed in Section 7.

\section{The expression of grammatical gender in standard and dialectal Dutch, Turkish, Moroccan Arabic and Berber}

\subsection{Standard Dutch: common and neuter gender}

Every Dutch noun has a grammatical gender. ${ }^{2}$ The main gender distinction is that between common (COM) and neuter (NTR) gender. Together with the number of a noun (singular or plural) gender determines the definite (DEF) determiner that can precede the noun: de or het (Table 1).

Nouns with common gender are the so-called de-words; nouns with neuter gender are labeled het-words. The determiner de is used with all de-words in the singular; the determiner het is used with all het-words in the singular. Plural nouns that are definite are always preceded by de and never by het:

2 Gender is a grammatical but lexically determined property of nouns. The referents which nouns refer to may or may not have a natural (or biological) gender and there is no direct correspondence between biological and grammatical gender (see Corbett 1991). 
Table 1: Determiners in Standard Dutch; forms contrasting in gender bold.

\begin{tabular}{llllll}
\hline & & Definite & & \multicolumn{2}{c}{ Indefinite } \\
\hline Gender & SG & PL & SG & PL \\
COM & de & de & een & - \\
NTR & het & de & een & - \\
\hline
\end{tabular}

(7)

$\begin{array}{lll}\text { de man } & \text { [COM.DEF.SG] } & \text { 'the man' } \\ \text { de mannen } & \text { [COM.DEF.PL] } & \text { 'the men' } \\ \text { het mannetje } & \text { [NTR.DEF.SG] } & \text { 'the little man' } \\ \text { de mannetjes } & \text { [NTR. DEF.PL] } & \text { 'the little men' }\end{array}$

The indefinite determiner for all cases is een in the singular; plural indefinite nouns are not preceded by a determiner:

(8)

$\begin{array}{lll}\text { een man } & \text { [COM.INDEF.SG] } & \text { 'a man' } \\ \emptyset \text { mannen } & \text { [COM.INDEF.PL] } & \text { 'men' } \\ \text { een mannetje } & \text { [NTR.INDEF.PL] } & \text { 'a little man' } \\ \varnothing \text { mannetjes } & \text { [NTR.INDEF.SG] } & \text { 'little men' }\end{array}$

Gender is not only visible on definite determiners, but also on demonstrative pronouns. ${ }^{3}$ In the singular, demonstrative pronouns vary in form according to the gender of the (antecedent) noun (Table 2). With respect to demonstrative pronouns, deze (nearby or proximal; PROX) or die (further away or distal; DIST) is required if the noun has common gender whereas neuter gender nouns require dit (nearby) or dat (further away).

The gender of a noun finally is also sometimes visible in adnominal elements, such as attributive adjectives, which precede indefinite nouns. Attributive

Table 2: Demonstrative pronouns in Standard Dutch; forms contrasting in gender bold.

\begin{tabular}{lll}
\hline Gender & SG & PL \\
\hline COM.PROX & deze & deze \\
COM.DIST & die & die \\
NTR .PROX & dit & deze \\
NTR.DIST & dat & die \\
\hline
\end{tabular}

3 Gender is also visible in standard Dutch relative pronouns, but these are not further discussed here. Regarding relative pronouns, die is required if the antecedent has common gender, while dat is used if the antecedent has neuter gender. 
adjectives always get a schwa suffix $(-e)$, except for neuter indefinite singular [NTR.INDEF. SG] nouns:

$\begin{array}{ll}\text { de kleine jongen } & \text { 'the little boy' } \\ \text { de kleine jongens } & \text { 'the little boys' } \\ \text { een kleine jongen } & \text { 'a little boy' } \\ \varnothing \text { kleine jongens } & \text { 'little boys' }\end{array}$

$\begin{array}{ll}\text { het kleine meisje } & \text { 'the little girl' } \\ \text { de kleine meisjes } & \text { 'the little girls' } \\ \text { een klein } \varnothing \text { meisje } & \text { 'a little girl' } \\ \varnothing \text { kleine meisjes } & \text { 'little girls' }\end{array}$

Notice that $\emptyset$ only occurs in one of four contexts: the neuter indefinite singular. ${ }^{4}$

The next issue to discuss is the predictability of Dutch grammatical gender. Approximately $75 \%$ of the nouns are common; the remaining $25 \%$ of the nouns are neuter (Haeseryn et al. 1997: 149). ${ }^{5}$ With underived nouns grammatical gender is arbitrarily determined, except for many animate-denoting words, which have common gender (Don et al. 1994: 129; Elektronische ANS ${ }^{6}$ ). A large part of the nouns is derived, however, and in most cases the gender of those nouns is predictable. The words in (11) are compounds:

$$
\begin{aligned}
& \text { de spelcomputer 'the game computer' } \\
& \text { het computerspel 'the computer game' }
\end{aligned}
$$

The gender of compounds is determined by their right-hand member (Don 2001: 116; Don et al. 1994: 42, 130): combining de computer and het spel thus yields de spelcomputer, but het computerspel.

In (12) some derived nouns are presented:
a. de aardigheid 'the nicety' de mensheid '(the) humanity' de moeilijkheid 'the difficulty'
b. het mannetje 'the little man' het kopje 'the little cup' het hondje 'the little dog'

\footnotetext{
4 The suffix $-e$ is also absent with the possessive pronoun ons 'our' and the question word welk 'which': (a) ons $\emptyset$ (kleine) meisje 'our (little) girl'welk (kleine) meisje? 'which (little) girl?'

5 Note that the skewing is much less pronounced in a corpus than in the dictionary. See van Berkum (1996: 24), who shows that the ratio of common to neuter gender is not 3:1 but 2:1 in running text. 6 http://ans.ruhosting.nl/e-ans/index.html $>$ Het woord $>$ Het substantief $>$ Genus $>$ De-woorden en het-woorden $>$ De-woorden $>$ Betekeniscategorieën. Last consulted November 27, 2018.
} 
With the nouns in (12) the gender is determined by the suffix attached (Booij and Van Santen 1998: 122; Don 2001: 116; Don et al. 1994: 43, 130): words ending in -heid are always common, as in (12a), while the diminutives ending in -tje (or its allomorphs such as $-j e$ ) are always neuter, as in (12b).

The nouns in (13) finally are nominalized bare verbs; such nouns are always common.

$$
\begin{aligned}
& \text { de val 'the fall' } \\
& \text { de was 'the laundry' }
\end{aligned}
$$

The examples so far illustrate that Dutch has a two gender system (Haeseryn et al. 1997: 147): common and neuter. Within common gender, traditionally, masculine and feminine nouns were distinguished in Standard Dutch. From that perspective one could say that modern standard Dutch has a three gender system (Haeseryn et al. 1997: 148).

The distinction between masculine and feminine words, which has otherwise collapsed (Postma and van Reenen 2009), is only relevant in Standard Dutch for reference by personal and possessive pronouns: masculine nouns are supposed to be referred to with hij 'he' and zijn 'his'; feminine nouns with zij 'she' and haar 'her'. It is not exactly clear, however, for many speakers, whether a common noun is feminine or masculine, apart from the obvious cases involving natural gender. Given the variation in pronominal reference especially in connection with neuter nouns, the system is changing in spoken standard Dutch (Audring 2006).

Finally, since only some $25 \%$ of all nouns is neuter and of those only some are singular indefinites, the absence of schwa with adjectives as in een klein $\emptyset$ meisje 'a little girl' is limited to a small set of contexts.

\subsection{Geographical dialect variation}

Since our research involved two cities at some geographical distance, Amsterdam and Nijmegen, a few words about geographical dialect variation are in order. In the southern dialect groups (Limburgian, Brabantic and Flemish), masculinefeminine-neuter is a grammatical three-way distinction with productive morphosyntactic manifestations (also in case inflection). Nijmegen borders on two of these dialect areas, Brabantic to the west and Limburgian in the south, in both of which traditionally three gender systems are found (in contrast with the Standard Dutch two gender system, but bordering on the three gender system in German). From the work of Hoppenbrouwers (1983) for a Brabant village we can conclude, however, that gender in some Brabant dialects perhaps has been under pressure from the standard language for some time now; for the Limburg dialects that hardly seems 
the case as yet. As in the case of spoken standard Dutch, in the local Flemish dialect of Moerzeke, pronominal reference shows indications that the gender system is changing, which De Vos and De Vogelaer (2011) attribute to language-internal factors. As a university town, Nijmegen attracts mainly Brabant and Limburg students - many of whom speak a variety of the respective dialect. ${ }^{7}$

Local non-standard varieties of Dutch in Amsterdam do not show a grammatical three-gender distinction. For our research this implies that we could possibly expect more sensitivity to fine-grained gender distinctions in the Nijmegen varieties of Dutch than in the Amsterdam varieties, since the former are spoken in a town bordering on a three gender dialect region.

\subsection{Gender in Turkish, Moroccan Arabic and Berber}

The community heritage languages of the Moroccan-Dutch and Turkish-Dutch speakers in our sample differ quite a bit in their gender distinctions. Turkish has no gender distinctions to speak of (Lewis 2000 [1967]). In the nominal morphology there is no gender and the personal pronoun system does not distinguish for gender either: the pronoun $o$ can be 'she' or 'he'.

In contrast, both Moroccan Arabic and Berber distinguish gender in various subsystems of the grammar. In Moroccan Arabic (Harrel 1962) there is even gender in the form of the second and third person of the verb in many conjugations. Thus (y)nsa 'forget' has $n s a$ 'he forgets' and nsa- $t$ 'she forgets'. All nouns are either masculine or feminine. Words ending in $-a$ are feminine and some words can be made feminine by adding an $-a$ :

$\begin{array}{ll}\text { Moroccan Arabic gender endings } \\ \text { ustad } & \text { 'male teacher' } \\ \text { ustada } & \text { 'female teacher' } \\ \text { xddam } & \text { 'working (M.PART)' } \\ \text { xddama } & \text { 'working (F.PART)' }\end{array}$

Likewise, demonstratives and definite articles are marked for gender: dak 'that (M.DEM)' and dik 'that (F.DEM)'. There are also yet other forms of noun phrase internal gender agreement. Altogether, it is clear that gender distinctions are a key element in Moroccan Arabic grammar.

Berber also makes a distinction between two genders. Masculine nouns generally begin with one of the three Berber vowels $a$, $u$ or $i$ : afus 'hand' and udem 'face'.

7 Especially because of the large number of students from the province of Limburg, Nijmegen is sometimes called the unofficial capital of Limburg. 
Feminine nouns derived from these are marked with a preceding $t$ - and a following - $t$ : tafust 'hand (diminutive)' and tudemt 'face (diminutive).' In Berber gender is not only overtly marked on the noun, it also surfaces in agreement (Kossmann 2000, 2007).

Taking the data for Turkish, Moroccan Arabic and Berber into account, we would expect that the Moroccan-Dutch speakers show greater sensitivity to gender distinctions in Dutch than the Turkish-Dutch speakers in our sample.

\section{Variation in the expression of grammatical gender in ethnic varieties of Dutch: a survey of the literature}

It has often been noted in the literature that there is overgeneralization of common gender in Dutch ethnolectal varieties. In fact, the acquisition of neuter gender in first language acquisition is also quite late.

Blom et al. (2008) and Blom and Vasić (2011) show that L1 learners of Dutch, Moroccan child L2 learners and Moroccan adult L2 learners of Dutch all overgeneralize common gender articles, also in neuter contexts. In all groups, the reverse is rarely found. While child learners overgeneralize one particular suffix (namely the schwa), adult learners use both adjectival forms, the schwa-adjective and the bare adjective, incorrectly.

Cornips et al. (2006), Hulk and Cornips (2006), Cornips (2008), Brouwer et al. (2008), and Cornips and Hulk (2008) studied the overgeneralization of common gender in the acquisition process of bilingual children in more detail. Their results reveal no significant difference between Moroccan-Dutch and Turkish-Dutch children, indicating that this overuse is not simply due to interference of the original language of the speakers (as we pointed out in Section 2.3 above, Turkish has no gender distinction, while Moroccan-Arabic and Berber do).

An earlier study of bilingual English-Dutch children by Unsworth (2008) confirms these findings, since the English-Dutch children also overgeneralize de for neuter nouns to a large extent. Furthermore, Unsworth's study shows that the overgeneralization of common gender is not restricted to children from immigrant communities. However, there seems to be a difference between the overgeneralization of children from immigrant communities (e.g., Moroccans and Turks) and the English-Dutch children Unsworth investigated.

While Unsworth's subjects did not overgeneralize common gender for stylistic purposes, and overgeneralized less frequently over time, Nortier and Dorleijn (2008) quote a Moroccan-Dutch informant who explicitly says that he knows how 
to use the Dutch gender system correctly, but that he overgeneralizes common gender on purpose when talking with friends.

In 5.2 below we will return to this aspect. Even though the expression of gender has been often discussed, there is very little systematic research on the variation in adolescent speakers and with a research design enabling the study of the origin of the variation, its place in the speakers' verbal repertoires and its social spread. In our study we hope to have filled this gap.

\section{The Roots of Ethnolects project}

The present authors were all involved in the Roots (of Ethnolects) project. $^{8}$ The research questions in the project are primarily descriptive, but also directed at specific research issues. The focus is on two components of the grammar: phonology and morphosyntax. In the Roots project spontaneous in-group conversations are recorded, and a set of elicitation tasks administered.

Three questions are geared towards disentangling the origins of the ethnolectal features. One concerns the role of L1. To what extent are ethnolects based on interference from the original language (L1) of the ethnic group in question? In other words, to what extent do ethnolectal features originate in the original mother tongues of both ethnic groups ("substrate effects")?

To answer this question, in the Roots project, young male Dutch speakers from Moroccan (Moroccan Arabic and/or Rif Berber) and Turkish backgrounds are compared - labeled $\mathbf{M}$ and $\mathbf{T}$, respectively. Language background of the parents (first generation speakers of Rif Berber and/or Moroccan Arabic, resp. Turkish) and place of birth (Amsterdam, resp. Nijmegen) are controlled for; and only speakers with strong inter-ethnic network ties are selected. The speakers' language use is systematically contrasted with the original languages of their community as well as with traditional Dutch. ${ }^{9}$

A second question focusing on the roots of the ethnolects concerns the extent to which we can reduce features of ethnolects to properties resulting from processes of L2 acquisition. Second language acquisition plays an important role in

8 This project was originally funded by the Dutch Research Council (NWO), see also www. rootsofethnolects.nl.

9 It is hard if not impossible to choose a proper term for both the language varieties and the speakers that belong to the dominant non-immigrant group of Dutch. Here we use the term 'traditional' to refer to this group and their variety of Dutch. They are not first or second generation immigrants. 
the emergence of ethnolects, although the ethnolect for the speakers themselves is the first language, maybe next to the community heritage language.

Generally speaking, language acquisition can leave two different types of traces behind: either interference from L1 or general, language independent characteristics of second language acquisition. ${ }^{10}$ Both kinds of acquisition traits are found in ethnolects. However, although ethnolects emerge in the context of second language acquisition, they are not fully determined by it, since they are not mere learner's varieties. These latter varieties are used to communicate, but their norms are - in contrast with norms of ethnolects - not rooted in the speech community. On the contrary, learner varieties as such are not subject to clear norms, and are therefore unstable and somehow fluctuate "between" varieties.

To determine the role of acquisition, in the Roots project (i) speakers of two age groups (12 and 20 years of age) are compared, and (ii) the data are systematically compared with existing recorded first and second language acquisition data from the relevant ethnic groups. Van Emmerik et al. (2014) investigated the acquisition of nominal gender by low-skilled adult L2 learners of Dutch from Turkish and Moroccan origins and deaf learners of Dutch (late L1 acquisition). They also had a low-skilled control group of Dutch L1 adults. In the study by van Emmerik et al., the Turkish and Moroccan learners are first generation immigrants. All groups had high accuracy scores for common nouns in a writing task (Turkish 92.6\%, Moroccan 96.6\%). Except for the control speakers, all groups had dramatically lower scores for the neuter nouns (Turkish 35.9\%, Moroccan 50.1\%). The Moroccans had higher scores, but the difference between the Turkish and Moroccan group was not significant. In the present study, the age comparisons are made to see to what extent socialization in the ethnolect takes place (sociolinguistic finetuning), and the data from acquisition are explored to see to what extent the ethnolect shows interlanguage features.

There may be an interaction between local dialect features and ethnolectal features (cf. the references to the Manningham accent in Bradford and to Glaswasian (Alam 2015) in Glasgow in the U.K.), and hence we want to investigate to what extent ethnolects are based on local non-standard varieties. In order to answer this question in the Roots project neighborhoods are studied in two large towns with quite different urban dialects: Amsterdam (specifically the neighborhood called Transvaal) and Nijmegen (various neighborhoods). These towns are chosen because both have been the object of systematic sociolinguistic studies of local urban dialects.

In addition to these three questions about the possible sources of the ethnolect features, we want to find out whether ethnolects are specific for an individual

10 The former ones are in principle identical for all L1s, the latter are specific for each single L1. 
ethnic group or rather reflect a more global non-majority identity. Do features spread across ethnolects? - a question inspired by the Scandinavian research on multi-ethnolects (cf. e.g., Quist 2008).

To establish to what extent ethnolects are specific for an individual ethnic group, or in contrast reflect a more global non-native identity in the Roots project first, specifically Turkish Dutch and specifically Berber Dutch features are compared to features common to the Dutch of both groups; second, informal conversations between Turkish-Dutch and Moroccan-Dutch (out-group contact) per urban setting are recorded; and third, the in-group recordings are systematically compared and contrasted with recordings from Dutch peer group speakers.

We also want to establish, following the work of Hewitt (1986) and Rampton $(1995,1998)$, whether there is any evidence of crossing or spread of ethnic varieties to peers outside of the ethnic groups involved? If so, do uniquely ethnolectal traits spread to peers outside the ethnic networks because of their covert prestige and/or also because they represent less marked options?

To find out whether there is any evidence of spread of ethnic varieties to peers outside of the ethnic group, in the Roots project in both cities two peer groups of Dutch speakers of comparable social backgrounds are recorded: a group with frequent contacts with Moroccan Arabic and Turkish background speakers of Dutch (D) and a group with few contacts with Moroccan and Turkish background speakers of Dutch (C). The latter group of speakers serves as the control group; statistically, it serves as the reference group for the effects of speaker background.

A final question in our research concerns the issue to what extent speakers of an ethnolect can shift to more standard varieties and to non-ethnic non-standard varieties. In the Roots project systematic comparisons are made of the language behavior of the members of the Turkish-Dutch and Moroccan-Dutch groups in various settings:

- in-group conversations,

- in out-group conversations with members of the other minority group and in out-group conversations with peers from traditional backgrounds,

- $\quad$ an experimental situation with elicitation tasks.

As is evident from the various research questions, the project is oriented towards linguistic and sociolinguistic rather than ethnographic aspects of ethnolectal variation. Attention focuses on the origins, generalizations and restrictions on variation, its spread through the speech community at large and its place in the verbal repertoires (cf. Hinskens 2011; van Meel 2016). Van Meel (2016) presents the outcomes of quantitative sociolinguistic analyses of three phonetic variables, their mutual coherence as well as their coherence with other variable features. 
Table 3: Summary of the speaker design (the $2 \times 3$ notation refers to the fact that the each of the six speakers in a 'cell' were each recorded in different interactive settings).

\begin{tabular}{|c|c|c|c|c|c|c|c|c|}
\hline \multirow{2}{*}{$\begin{array}{l}\text { Background } \\
\text { Inter-ethnic ties? }\end{array}$} & \multirow{2}{*}{\multicolumn{2}{|c|}{$\begin{array}{c}\begin{array}{c}\text { Moroccan- } \\
\text { Dutch (M) }\end{array} \\
\text { Strong }\end{array}$}} & \multirow{2}{*}{\multicolumn{2}{|c|}{$\begin{array}{r}\begin{array}{r}\text { Turkish- } \\
\text { Dutch (T) }\end{array} \\
\text { Strong }\end{array}$}} & \multicolumn{4}{|c|}{ Traditional Dutch } \\
\hline & & & & & \multicolumn{2}{|c|}{ Strong (D) } & \multicolumn{2}{|c|}{ weak (C) } \\
\hline Years of age & $10-12$ & $18-20$ & $10-12$ & $18-20$ & $10-12$ & $18-20$ & $10-12$ & $18-20$ \\
\hline Amsterdam & $2 \times 3$ & $2 \times 3$ & $2 \times 3$ & $2 \times 3$ & $2 \times 3$ & $2 \times 3$ & $2 \times 3$ & $2 \times 3$ \\
\hline Nijmegen & $2 \times 3$ & $2 \times 3$ & $2 \times 3$ & $2 \times 3$ & $2 \times 3$ & $2 \times 3$ & $2 \times 3$ & $2 \times 3$ \\
\hline
\end{tabular}

To answer all the questions raised in our research project, we needed a speaker design in which ethnic background, age, city and, for the speakers with a traditional background, the presence or absence of regular contacts with Turkish-Dutch and Moroccan-Dutch are interwoven. Table 3 shows how this is obtained.

What this table does not show is the "within subjects factor" ingroup-outgroup contact, a situational factor which is relevant to questions about spread and style shifting.

As pointed out above, relatively spontaneous conversations were recorded both in in- and out-group contact situations. An early step in the analyses of these data consists of drawing up inventories of non-standard features.

For the present study, data were analyzed for the speakers in what we refer to as the "core corpus", which is a proper subset of the data from the overall design (Table 4)

Most data were coded by Ariën van Wijngaarden. Statistical analyses included mixed models logistic regression. Researchers interested in the data underlying the analyses presented in this article are encouraged to contact the authors.

\section{Findings}

In this section we first present the findings for the effects of both the extralinguistic and the linguistic factor groups. In both respects, grammatical gender (common vs. neuter) and its expression (on determiners and adjectival elements) are central.

The first main finding is that the inflection of the determiners and adnominal elements (in our data mainly adjectives) before common nouns hardly shows any variation; cf. Figure 1.

As all groups of speakers appear to use almost 100\% standard forms for common nouns, we focus on neuter gender marking. We will first discuss the variation in the determiner system. 
Table 4: Summary of the speaker design for the "Core corpus", analyzed for the present study (numbers of speakers per subgroup).

\begin{tabular}{|c|c|c|c|c|c|c|c|c|}
\hline \multirow{2}{*}{$\begin{array}{l}\text { Background } \\
\text { Inter-ethnic ties? }\end{array}$} & \multirow{2}{*}{\multicolumn{2}{|c|}{$\begin{array}{c}\begin{array}{c}\text { Moroccan- } \\
\text { Dutch (M) }\end{array} \\
\text { Strong }\end{array}$}} & \multirow{2}{*}{\multicolumn{2}{|c|}{$\begin{array}{r}\begin{array}{r}\text { Turkish- } \\
\text { Dutch (T) }\end{array} \\
\text { Strong }\end{array}$}} & \multicolumn{4}{|c|}{ Traditional Dutch } \\
\hline & & & & & \multicolumn{2}{|c|}{ Strong (D) } & \multicolumn{2}{|c|}{ Weak (C) } \\
\hline Years of age & $10-12$ & $18-20$ & $10-12$ & $18-20$ & $10-12$ & $18-20$ & $10-12$ & $18-20$ \\
\hline Amsterdam & 3 & 4 & 3 & 4 & 2 & 3 & 3 & 3 \\
\hline Nijmegen & 3 & 3 & 3 & 3 & 3 & 3 & 4 & 4 \\
\hline
\end{tabular}

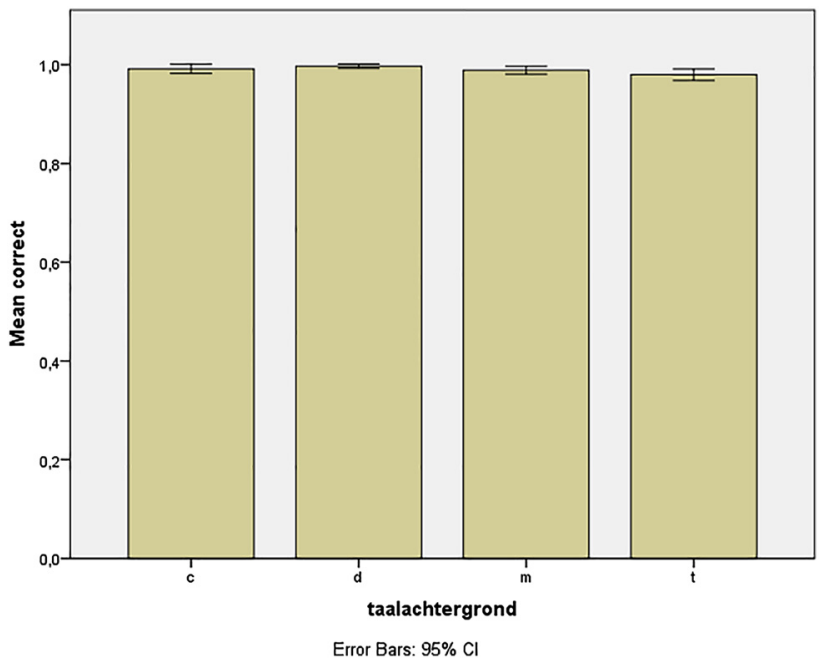

Figure 1: Common gender: average usage of standard flexion per background.

\subsection{Determiners}

The data consist of 755 occurrences, realized by 52 speakers, an average of 14.52 occurrences per speaker, with large differences in frequency between speakers ( $\mathrm{SD}=7.56$; minimum is 3, maximum is 40 occurrences). In all, 278 different lexical items occur in the data, with 160 hapax legomena, and only 12 words have a token frequency of 10 or larger; the mean word token frequency is 2.72 (SD 5.00).

About one quarter of the forms used by our speakers are not standard neuter forms but rather common gender forms such as definite article de, proximal demonstrative deze, and distal die. Mixed effects logistic regression analyses (glmer, lme4 package, $\mathrm{R}$ ) were run with speakers as random effect; words were not included as a random factor, as there are too many empty cells when cross- 
classified with speakers. The background of both speakers and interlocutors were dichotomized to have sufficient numbers of speakers (C, D versus $M, T$ ). The dependent variable was a neuter form (1) or a common form (0). We included four extra-linguistic factors (see Table 5) and three linguistic ones: diminutive yes or no, animacy yes or no, and demonstrative vs. article. ${ }^{11}$ We tested all two- and threeway interactions. The best model found, using the AIC as the index to evaluate models, is given in Table 5 . The best model has only one two-way interaction, containing the only linguistic factor that survived, demonstrative die.

First, as to the speakers' backgrounds: Table 5 shows that the Turkish Dutch and Moroccan Dutch speakers use significantly fewer standard neuter forms than the speakers from the other groups (see Figure 2 below, columns labeled ' $m$ ' and ' $t$ ' versus 'c' and 'd'). Second, the 18-20 year old speakers use more standard neuter forms than the 10-12 year olds (the green and blue bars, respectively, in Figure 2) and this probably points towards an overall acquisition effect. Third, the Nijmegen speakers use significantly fewer neuter forms than their Amsterdam counterparts (lower and upper graph in Figure 2, respectively). The fact that Nijmegen borders on dialect areas with three-gender systems and that considerable numbers of speakers of the relevant dialects live in Nijmegen (Section 2.1 above) may well play a role here. The background of the interlocutor has an effect in that neuter standard forms are used less frequently in interaction with Turkish and Moroccan Dutch interlocutors, also by 'd' speakers (Figure 3), is a clear style and audience design effect (Bell 1984).

Three internal factor groups were studied: one of them regarding the determiner type, and the other ones a formal and a semantic property of the noun: is it a diminutive or not (diminutives are always treated as grammatically neuter) and

Table 5: Significant effects of the best model for variation in the determiners for neuter heads (Akaike IC 668.5).

\begin{tabular}{lrrr}
\hline Main effects & Estimate & Standard error & $p$ \\
\hline Extra-linguistic & & & \\
$\quad$ Speaker background T+M & -1.7432 & 0.3592 & $0.000^{\star \star \star}$ \\
$\quad$ Age 18-20 years & 1.3170 & 0.2952 & $0.000^{\star \star \star}$ \\
$\quad$ City Nijmegen & -0.9068 & 0.2935 & $0.002^{\star \star}$ \\
$\quad$ interloc.background T+M & -0.5286 & 0.2356 & $0.024^{\star}$ \\
Linguistic & & & \\
$\quad$ Demonstrative die & 0.4241 & 0.5050 & 0.405 \\
Interaction effects & & & \\
$\quad$ Speaker background T+M $\times$ demonstr die & -2.1267 & 0.5662 & $0.000^{\star \star \star}$ \\
\hline
\end{tabular}

11 The first two linguistic factors were discussed in Section 2.1 above, the third one in Section 1. 

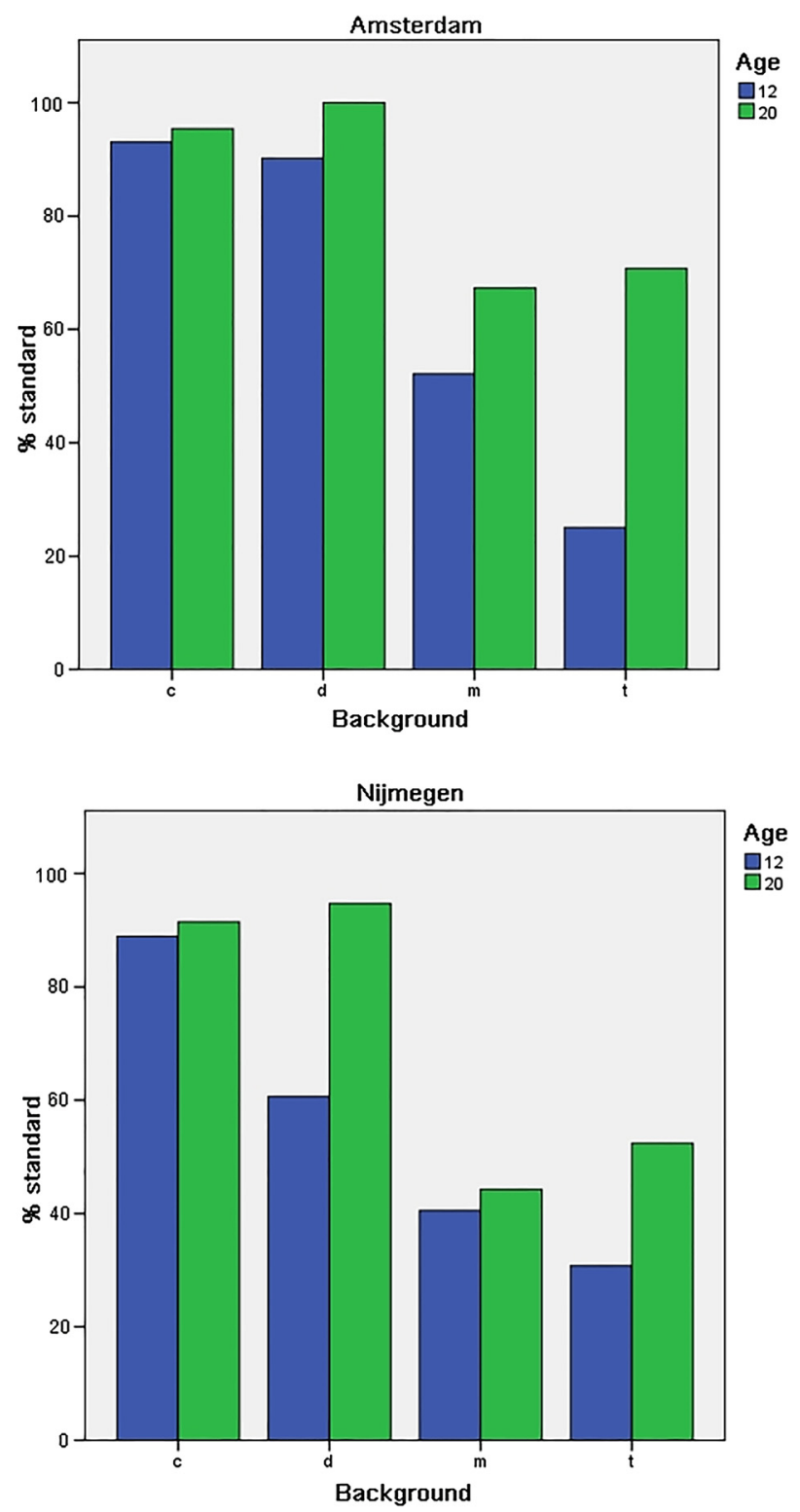

Figure 2: Percentage of usage of standard determiner forms for neuter heads broken down for speaker background, age group and city. 


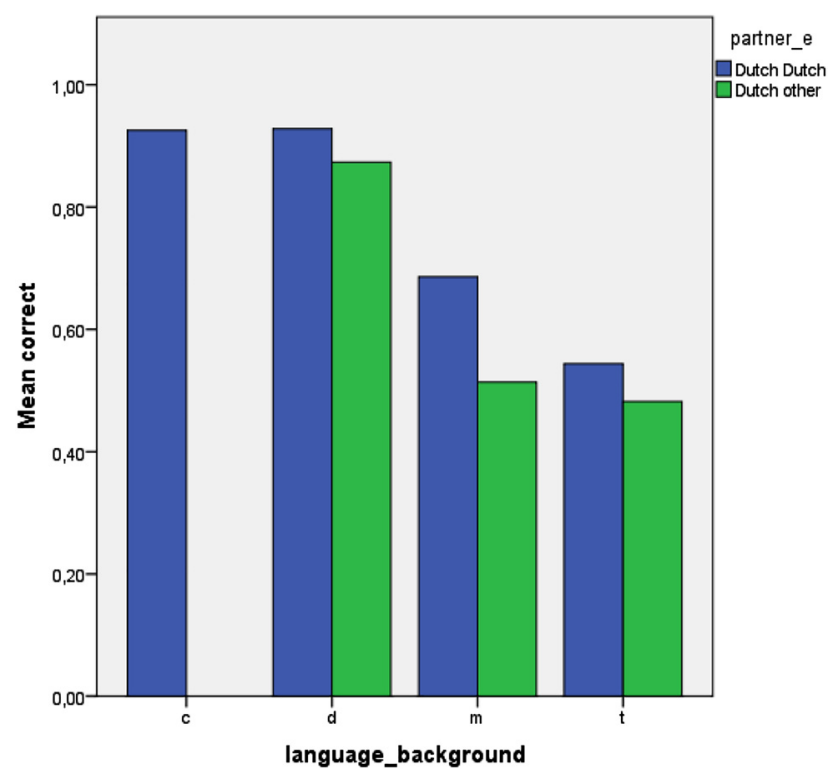

Figure 3: Percentage of usage of standard determiner forms for neuter heads broken down for the background of the interlocutor ('partner').

does it refer to an animate entity or not. There are no statistically significant main effects of any of the three internal factor groups. This is especially remarkable for the factor group simplex/diminutive, as in Dutch the diminutive is one of the not so many lexical domains ${ }^{12}$ where grammatical gender is formally predictable.

The determiner type is involved in a statistically significant interaction with speaker background; see Figure 4 below. In standard Dutch neuter determiner types are definite article het and proximal demonstrative dit (blue bars) or distal demonstrative dat (green bars). The non-standard variants in our data are common gender forms. The Moroccan and Turkish Dutch show remarkably high nonstandard, common gender scores for the distal demonstrative die, such as die boekje, die raam for standard Dutch dat boekje 'this little book', dat raam 'this

12 Along with nouns derived with an affix such as deadjectival formations with -heid (e.g., waarheid, 'truth' from waar 'true'), as discussed in Section 2.1 above, as well as-de/-te (liefde, diepte, 'love', 'depth' from lief 'dear' and diep 'deep'), deverbal formations with -(r)ij (bedriegerij, 'deceit, swindle' from bedriegen 'to deceive'), all of which have common gender. Nominalizations of verbal infinitives are neuter gender formations (het zwemmen, 'the swimming'), while affix-less conversions of verb forms (de schreeuw, 'the shout, the scream') are common gender formations. Cf. https:// en.wikipedia.org/wiki/Gender_in_Dutch_grammar and http://taalportaal.org/taalportaal/topic/ pid/topic-14419054999947754 (accessed November 23, 2017). See Salmons (1993) on gender assignment in German, which has a three-gender system. 


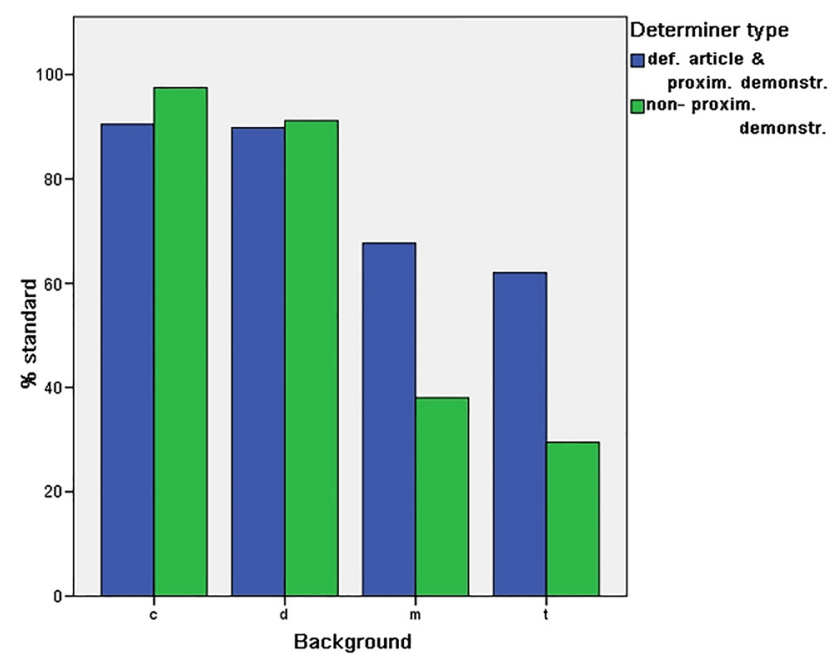

Figure 4: Percentage of usage of standard determiner forms for neuter heads broken down for determiner type.

window'; this variant makes up over $60 \%$ of the Moroccan Dutch and almost $70 \%$ of the Turkish Dutch distal demonstrative realizations. For the proximal demonstratives and the definite articles we do not find an effect of this type.

\subsection{Adnominals}

For the adnominals (including attributive adjectives), the analyses were confined to indefinites; after all, as was pointed out in Section 2.1, for indefinites with a neuter head the schwa ending is optional in standard Dutch: het / dit klein(e) meisje, 'the / this little girl'.

For the D, M and T speakers our data consist of 277 observations, 73 of which are non-standard forms, such as e.g., een klein-e meisje, 'a little-INFL girl'. These 277 occurrences were realized by 37 speakers (a proper subset of the speakers in the core corpus - for the remaining 14 speakers, our transcriptions did not contain any instances of an adnominal preceding grammatically neuter nouns). This amounts to an average of 7.49 occurrences per speaker, with differences in frequency between speakers ( $\mathrm{SD}=3.43$; minimum is 2 , maximum is 15 occurrences). In all, 122 different items occur in this part of the data, with 79 hapax legomena, and only 3 words having a frequency of 10 or more. The mean word frequency of usage is 2.27 (SD 2.96).

All these cases concern overuse of the schwa suffix. Table 6 summarizes the main outcomes of the mixed models logistic regression with speakers as a random 
effect (glmer, lme4 package, R; words were not included as a random factor, as there are too many empty cells when cross-classified with speakers).

In this model (i.e., the one with the highest Akaike IC, hence the best fit), there are no main effects for the extra-linguistic variable city, nor for the linguistic variables diminutive or non-diminutive head and the presence or absence and the nature of the determiner (not all speakers realize a determiner). Neither are there any significant interaction effects between the various independent variables.

The variation between standard and non-standard inflection is determined only by two of the extra-linguistic parameters and one of the linguistic parameters. The extra-linguistic parameters are speaker background and age group; proportionally, the Moroccan-Dutch and Turkish-Dutch use most non-standard inflected forms, as do the 10-12 year olds. See Figure 5.

The linguistic factor animacy appears to be a prominent determiner of the variation, with inanimate heads being the main predictor of non-standard schwasuffixation to the adnominal element. Further study is needed to determine why inanimate neuter nouns attract common gender marking. Is it a case of (re)semanticization (Audring 2006; Dahl 1999)? In nouns referring to animate entities, biological gender seems to outweigh grammatical gender (genus), as in e.g., de meisje; de wijf; de jongetje; de dier ('the girl', 'the woman', 'the boy in standard Dutch these nouns have neuter gender (and thus select the definite article het). We find this relatively often in the speech of Moroccan Dutch and Turkish Dutch speakers, although our data do not display a statistically significant interaction effect between the +/- animacy semantics of the noun and the speakers' background.

\subsection{Comparing determiners and adnominals}

While all four social parameters (viz. background of the speaker, background of the interlocutor, speaker's age and city) were found to play a role in the variation in the determiners, only two of them do so in the inflection of adnominals. In both contexts, speaker background has a stronger statistical effect than speakers' age. The

Table 6: Significant effects for variation in the determiners for neuter heads (Akaike IC 294.1).

\begin{tabular}{lrrr}
\hline Main effects & Weight & Standard error & $\boldsymbol{p}$ \\
\hline Extra-linguistic & & & \\
Speaker backgr T & -1.6034 & 0.3944 & $0.000^{\star *}$ \\
18-20 year old & 0.1053 & 0.0372 & $0.005^{\star}$ \\
Linguistic & & & \\
Inanimate & -1.5401 & 0.4413 & $0.009^{\star}$ \\
\hline
\end{tabular}




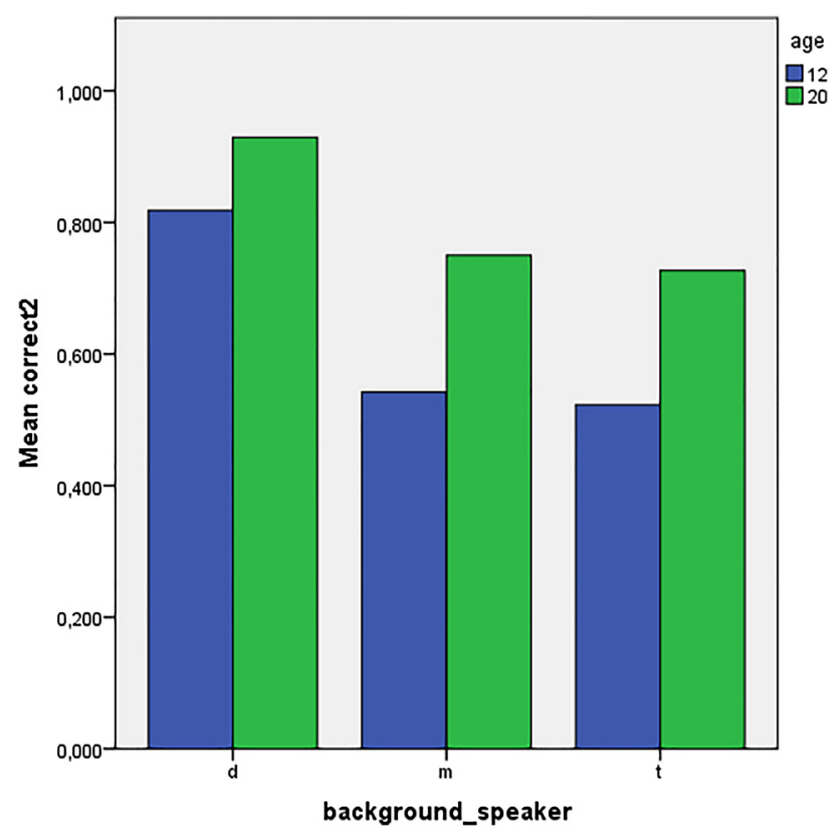

Figure 5: Percentage of usage of standard inflected adnominal forms for indefinite neuter heads broken down for speaker background and age group.

direction of the effects are the same in both contexts, with a negative effect exerted by a Moroccan Dutch and (even more so) Turkish Dutch background and a positive one for the 18-20 year old age group - meaning that the older speakers produced more standard forms than the younger ones. In contrast to the determiners, the surrounding (urban, regional) dialects do not seem to affect the variation in adnominal inflection.

Variation in determiners and in adnominals are both internally conditioned, but by different parameters. For the variation in the determiners, the speakers' background interacts with each of the determiner types. The variation in the adnominal inflection does not show any such interaction effects; it is only sensitive to the semantic property animacy of the head, meaning that this effect occurs as well in the traditional Dutch group. See the summary in Table 7.

\section{Discussion}

What does all this mean? How do the findings relate to our main questions regarding the linguistic origins of ethnolect features, the place of ethnolect in the verbal repertoires and the spread of ethnolectal features to other ethnic groups? 
Table 7: Comparing significant effects for variation in the determiners to that in adnominals (both for neuter heads).

\begin{tabular}{lrr}
\hline & Determiner & Adnominal \\
\hline Main effects & & \\
Extra-linguistic & + & + \\
Background speaker & + & - \\
Background interlocutor & + & + \\
Age & + & + \\
$\quad$ City & & \\
Linguistic & - & - \\
Animacy & & \\
Interaction effects & + & \\
Background spr $\times$ non-prox.dem & & \\
\hline
\end{tabular}

As regards the roots of the variation in grammatical gender marking: this is clearly a second language phenomenon. There is a strict, one-way overuse neuter $\rightarrow$ common, hardly ever the other way around; this is visible among other things in overuse of the non-neuter definite article de over neuter het and in overuse of the generic inflected adjective rather than the non-inflected article limited to neuter indefinite contexts. This overuse of common gender is much stronger than in the L1 and L2 acquisition data reported in the literature (cf. Section 3). With its full vowel, the emphatic common gender distal demonstrative die may be more accessible to adult learners; what looks like the emergent replacement of the definite article $d e$ (also in its non-standard use as neuter definite article) with die may thus be rooted in a second language effect (the parents of the $\mathrm{T}$ and $\mathrm{M}$ speaker groups, generally first generation migrants).

Especially in adnominal inflection there seems to be a tendency towards a new regularity with biological gender outweighing grammatical gender. This amounts to the development of a much more regular and transparent grammar. What adds to the interpretation of these patterns as acquisition effects is the fact that overall there are significant age effects, manifested in the use of more correct standard forms by the older ethnolect speakers.

For the adnominals, the acquisition effect is probably amplified by general tendencies towards deflection in the Dutch diasystem at large and for the determiners by dialect geography, more in particular properties of the surrounding endogenous dialects (see Section 2.2 above). In the Nijmegen area, which borders on Dutch dialectal and German three-gender areas, language learners may well receive input from both common-neuter and masculine-feminine-neuter systems and the variation Common versus Masculine-Feminine, which is largely located in articles, demonstratives and adnominal inflection as well as in 3SG pronouns, may 
require so much processing energy and storage space that it weakens the cognitive position of the neuter.

What role does this specific variation have in the speakers' verbal repertoires? To tell from the effect of the interlocutors' background on variation in the determiner, there is evidence of style shifting linked to audience design. Moreover, the data indicate that there may be stylization going on with respect to what looks like the overuse by Moroccan Dutch and Turkish Dutch speakers of the common gender distal demonstrative die in contexts where the use of demonstratives seems uncommon in traditional varieties of Dutch. An example is (15), where speakers of traditional Dutch would have said 'het hele land'.

die is gewoon die hele land

'he is just the whole country'

(Abdelaziz, a 20 year old Moroccan Dutch from Amsterdam)

The traditional Dutch distal demonstrative 'dat hele land' would not be appropriate here. Acton and Potts (2014: 23) argue that in the speech of Sarah Palin during TV interviews distal demonstratives serve as "vehicles for establishing and maintaining social bonds". Independent of the fact that in (16) the 'wrong' gender is used, here and in similar cases in our data distal demonstratives do not seem to play that role. Non-standard variation in gender marking, especially the use of the salient emphatic common gender form die in non-emphatic neuter contexts and the omnipresent schwa on adnominal forms, may have acquired a social symbolic meaning for speakers of Dutch ethnolects, turning them into targets of speaker agentivity, possibly expressing a more global non-native identity (cf. Johnstone's et al. 2006 indexicality concept). This is an issue for future research.

In our data there is no significant difference between the two groups of traditional Dutch speakers, i.e., the ones with strong and the ones with weak interethnic ties. Neither is there any statistical evidence of spread to members of the D group, i.e., traditional Dutch speakers with strong interethnic network ties, although six of the 11 speakers of this type in our sample do incidentally use non-standard (common gender) inflection in neuter contexts. An example is realized by a Nijmegen 12 years old in a conversation with a peer with a Turkish-Dutch background.

een witte dier

'a white animal'

But non-standard forms are also used with D interlocutors, as in (17), realized by a Nijmegen 20 years old.

een of andere mannetje achter een bureau

'some little fellow behind a desk' 
Three of the D speakers who have been observed to use non-standard inflected adnominals are from Amsterdam (one of them 10-12 years of age, two of them 1820 years old), the other three are from Nijmegen (two of them 10-12 year of age, one of them 18-20 years old). With the exception of one Amsterdam 20 years old and one Nijmegen 12 years old, all speakers produced one single non-standard inflected adnominal form. Of the 10 cases of non-standard inflection ${ }^{13}$ produced by these six D speakers, seven were realized in a conversation with a peer without a migration background (hence another representative of the D set). ${ }^{14}$

Overall, Turkish Dutch speech seems to display the lowest proportions of standard Dutch forms - which is what we expected since Turkish does not have grammatical gender, unlike Moroccan Arabic and Berber. But the 20 year old Moroccan Dutch deviate from this general pattern. Are they borrowing this phenomenon from Turkish Dutch or expressing and claiming their own ethnolect position? Although it may rather reflect a more global non-native identity in general, it is clearly used by our Moroccan-Dutch and Turkish-Dutch informants to mark their ethnicity.,

\section{Issues for future research}

The fact that grammatical gender varies in a variety of Dutch spoken by members of communities with many second language learners of Dutch does not come as a big surprise; ethnolects are perhaps ahead of future changes in Dutch. The fact that in endogenous varieties of Dutch the grammatical gender system appears to be increasingly dismantled does not come as a big surprise either. Especially in underived nouns, gender adds opaque, meaningless and/or functionless substantial complexity - “junk, historical debris” in Lass' (1997: 316) terminology. Nevertheless, crucial questions remain concerning the internal and social trajectories of the dismantlement process.

First of all, the variable presence or absence of the determiner in environments where endogenous varieties of Dutch require a determiner deserves closer analysis (cf. Section 5.2 above). Schönenberger (2014) found that monolingual German and bilingual Turkish-German children (around 4 years old, followed for 20 months),

13 Out of the sample total of 73.

14 It is striking that a search on Google or Twitter for non-standard expressions including the - $e$ such as een leuk-e meisje 'a nice girl' (standard een leuk meisje) or een grot-e problem 'a big problem'(standard een groot probleem) yields hundreds if not thousands of hits, often from authors who clearly do not have an immigrant background. This requires much further study. 
showed a clear difference in determiner omission, but not in 'article misuse', i.e., the inappropriate use of a definite/indefinite determiner.

Next, we have not yet analyzed a set of data elicited at a later stage than our initial recordings with similar speaker groups. In case the elicited data show different patterns, the question arises whether this is related to the stylistic difference between conversational and scripted speech.

Then, experimental studies could throw further light on two issues raised by our findings so far. The first one concerns the remarkable finding that animacy plays a statistically significant role in conditioning the use of adnominal schwa with neuters (see Section 5). The second one concerns the social-emblematic status of adnominal schwa as hypothesized by Nortier and Dorleijn (2008); our conversational data show that this variation is clearly related to the speaker background.

The spread of the distal demonstrative die to determiner contexts also merits further exploration, since it is a feature of several languages related to Dutch which have arisen in situations of intensive language contact in the 17th and 18th centuries, such as Afrikaans and Virgin Islands Dutch Creole (also known as "Negerhollands"). In these languages (which have no grammatical gender), die serves as the definite article.

$\begin{array}{llll} & \text { standard Dutch } & \text { Afrikaans } & \text { VIDC } \\ \text { 'the man' } & \text { de man } & \text { die man } & \text { di man } \\ \text { 'the woman' } & \text { de vrouw } & \text { die vrou } & \text { di vrow } \\ \text { 'the child' } & \text { het kind } & \text { die kind } & \text { di kind }\end{array}$

In short, there is still enough work to do concerning the dismantlement of grammatical gender and related morphosyntax in ethnolectal varieties and daughter languages of Dutch.

Acknowledgements: The research reported on here was carried out in the Roots of Ethnolects project, originally funded by the Dutch Research Council (NOW) (see also www.rootsofethnolects.nl). We are grateful for comments from the reviewers.

\section{References}

Acton, Eric K. \& Christopher Potts. 2014. That straight talk: Sarah Palin and the sociolinguistics of demonstratives. Journal of Sociolinguistics 18(1). 3-31.

Alam, Farhana. 2015. ‘Glaswasian'? A sociophonetic analysis of Glasgow-Asian accent and identity. Glasgow: University of Glasgow Dissertation.

Audring, Jenny. 2006. Pronominal gender in spoken Dutch. Journal of Germanic Linguistics 18. 85-116. 
Bell, Alan. 1984. Language style as audience design. Language in Society 13(2). 145-204.

Blom, Elma \& Nada Vasić. 2011. The production and processing of determiner-noun agreement in child L2 Dutch. Linguistic Approaches to Bilingualism 1(3). 265-290.

Blom, Elma, Daniela Polišenská \& Fred Weerman. 2008. Articles, adjectives and age of onset: The acquisition of Dutch grammatical gender. Second Language Research 24(3). 297-331.

Booij, Geert \& Arianne van Santen. 1998. Morfologie. De Woordstructuur van het Nederlands. 2e geheel herziene druk. Amsterdam: AUP.

Brouwer, Susanne, Leonie Cornips \& Aafke Hulk. 2008. Misrepresentation of Dutch neuter gender in older bilingual children? In Belma Hazdenar \& Elena Gavruseva (eds.), Current trends in child second language acquisition: A generative perspective (Language Acquisition \& Language Disorders 46), 83-96. Amsterdam \& Philadelphia: John Benjamins.

Chini, Marina. 2011. New linguistic minorities: Repertoires, language maintenance and shift. International Journal of the Sociology of Language 210. 47-69.

Clyne, Michael. 2003. Dynamics of language contact: English and immigrant languages. Cambridge: Cambridge University Press.

Corbett, Greville. 1991. Gender. Cambridge: Cambridge University Press.

Cornips, Leonie. 2008. Loosing grammatical gender in Dutch. The result of bilingual acquisition and/or an act of identity. International Journal of Bilingualism 12(1/2). 105-124.

Cornips, Leonie \& Aafke Hulk. 2008. Factors of success and failure in the acquisition of grammatical gender in Dutch. Second Language Research 24(3). 267-296.

Cornips, Leonie, Mara van der Hoek \& Ramona Verwer. 2006. The acquisition of grammatical gender in bilingual child acquisition of Dutch (by older Moroccan and Turkish children): The definite determiner, attributive adjective and relative pronoun. In Jeroen van de Weijer \& Bettelou Los (eds.), Linguistics in the Netherlands 2006, 40-51. Amsterdam \& Philadelphia: John Benjamins.

Dahl, Östen. 1999. Animacy and the notion of semantic gender. In Barbara Unterbeck \& Matti Rissanen (eds.), Gender in grammar and cognition, vol. 2: Manifestations of gender, 99-115. Berlin \& New York: Mouton De Gruyter.

De Elektronische ANS. http://ans.ruhosting.nl/e-ans/index.html.

De Vos, Lien \& Gunther De Vogelaer. 2011. Dutch gender and the locus of morphological regularization. Folia Linguistica 45(2). 245-282.

Don, Jan, Wim Zonneveld, Frank Drijkoningen, Martin Everaert, Mieke Trommelen and Wiecher Zwaneburg. 1994. Inleiding in de generatieve morfologie. Bussum: Coutinho.

Don, Jan. 2001. Dé afwas gaat in hét sop. Het (on)voorspelbare geslacht van Nederlandse woorden. Onze Taal 70, 116-118.

Doran, Meredith Christine. 2002. A sociolinguistic study of youth language in the Parisian suburbs: Verlan and minority identity in contemporary France. Ithaca, NY: Cornell University Dissertation.

Doran, Meredith Christine. 2004. Negotiating between Bourge and Racaille: 'Verlan' as youth identity practice in suburban Paris. In Aneka Pavlenko \& Adrian Blackledge (eds.), Negotiation of identities in multilingual contexts, 93-124. Clevedon: Multilingual Matters.

Doran, Meredith Christine. 2007. Alternative French, alternative identities: Situating language in la Banlieue. Contemporary French \& Francophone Studies 11(4). 497-508.

Fagyal, Zsuzanna \& Christopher Stewart. 2011. Prosodic style-shifting in preadolescent peergroup interactions in a working-class suburb of Paris. In Friederike Kern \& Margret Selting (eds.), Ethnic styles of speaking in European metropolitan areas, 75-99. Amsterdam \& Philadelphia: John Benjamins. 
Haeseryn Walter, Kirsten Romijn, Guido Geerts, Jaap de Rooij \& Maarten van den Toorn. 1997. Algemene Nederlandse Spraakkunst. Tweede, geheel herziene druk. Groningen/Deurne: Martinus Nijhoff uitgevers/Wolters Plantyn.

Harrel, Richard S. 1962. A short reference grammar of Moroccan Arabic. Washington, DC: Georgetown University Press.

Hewitt, Roger. 1986. White talk black talk: Inter-racial friendship and communication amongst adolescents. Cambridge: Cambridge University Press.

Hinskens, Frans. 2011. Emerging Moroccan and Turkish varieties of Dutch: Ethnolects or ethnic styles? In Friederike Kern \& Margret Selting (eds.), Ethnic styles of speaking in European metropolitan areas, 103-131. Amsterdam \& Philadelphia: John Benjamins.

Hoppenbrouwers, Cor. 1983. Het genus in een Brabants regiolect. Tabu 13(1): 1-25.

Hulk, Aafke \& Leonie Cornips. 2006. The acquisition of definite determiners in child L2 Dutch: Problems with neuter gender nouns. In Sharon Unsworth, Teresa Parodi, Antonella Sorace \& Martha Young-Scholten (eds.), Paths of development in L1 and L2 acquisition, 107-134. Amsterdam \& Philadelphia: John Benjamins.

Johnstone, Barbara, Jennifer Andrus \& Andrew Danielson. 2006. Mobility, indexicality, and the enregisterment of "Pittsburghese". Journal of English Linguistics 34(2). 77-104.

Kossmann, Maarten. 2000. Esquisse grammaticale du rifain oriental. Paris: Peeters.

Kossmann, Maarten. 2007. Grammatical borrowing in Tasawaq. In Yaron Matras \& Jeanette Sakel (eds.), Grammatical borrowing in cross-linguistic perspective, 75-90. Berlin \& New York: Mouton De Gruyter.

Lass, Roger. 1997. Historical linguistics and language change. Cambridge: Cambridge University Press.

Lewis, Geoffrey. 2000[1967]. Turkish grammar, 2nd edn. Oxford: Oxford University Press.

Muysken, Pieter. 2010. Ethnolects as a multidimensional phenomenon. In Muriel Norde, Bob de Jonge \& Cornelius Hasselblatt (eds.), Language contact, 7-26. Amsterdam \& Philadelphia: John Benjamins.

Muysken, Pieter. 2013. Ethnolects of Dutch. In Frans Hinskens \& Johan Taeldeman (eds.), Language and space: Dutch, 739-761. Berlin \& Boston: De Gruyter Mouton.

Muysken, Pieter \& Julian Rott. 2013. Ethnolect research in the German and Netherlandic area. In Siemund Peter, Ingrid Gogolin, Monika Edith Schulz \& Julia Davydova (eds.), Multilingualism and language diversity in urban areas: Acquisition, identities, space, education, 177-206. Amsterdam \& Philadelphia: John Benjamins.

Nortier, Jacomine M. \& Margreet Dorleijn. 2008. A Moroccan accent in Dutch: A socio-cultural style restricted to the Moroccan community? International Journal of Bilingualism 12(1/2). 125-143.

Postma, Gertjan \& Piet van Reenen. 2009. De wisselwerking tussen spontane palatalisatie, Umlaut en genus. Taal en tongval 18. 109-152. [English translation: Gertjan Postma: 'Language-internal mechanisms of koineisation: 3-to-2 gender decay in the Northern Netherlands'. https://www.academia.edu/4132995/Language-internal_mechanisms_of_ koineization-3-to-3_gender_decay_in_the_Northern_Netherlands.

Quist, Pia. 2008. Sociolinguistic approaches to multiethnolect: Language variety and stylistic practice. International Journal of Bilingualism 12(1/2). 43-62.

Rampton, Ben. 1995. Crossing. Language and ethnicity among adolescents. London: Longman. Rampton, Ben. 1998. Language crossing and the redefinition of reality. In Peter Auer (ed.), Code-switching in conversation, 290-317. London: Routledge. 
Salmons, Joe. 1993. The structure of the lexicon: Evidence from German gender assignment rules. Studies in Language 17. 411-435.

Schönenberger, Manuela. 2014. The acquisition of determiners in child L2 German. Folia Linguistica 48(1). 169-224.

Unsworth, Sharon. 2008. Age and input in the acquisition of grammatical gender in Dutch. Second Language Research 24. 365-396.

van Berkum, Jos. 1996. The psycholinguistics of grammatical gender. Nijmegen: Nijmegen University Press.

van Emmerik, Joanne, Jetske Klatter, Roeland van Hout, Ineke van de Craats \& Job Schepens. 2014. Acquiring nominal gender by deaf learners and hearing adult second language learners of Dutch. Communication Disorders. Deaf Studies \& Hearing Aids 2(2). 1-9.

van Meel, Linda. 2016. The roots of ethnolects. A sociophonological study in Amsterdam and Nijmegen. Nijmegen: Radboud Universiteit Nijmegen Dissertation. http://www.lotpublications. $\mathrm{nl} /$ the-roots-of-ethnolects. 